\title{
Ferritin 1 silencing effect in Rhipicephalus sanguineus sensu lato (Acari: Ixodidae) during experimental infection with Ehrlichia canis
}

\author{
Joana Ferrolho a , Sandra Antunes ${ }^{\mathrm{a}, \mathrm{c}}$, Gustavo S. Sanches ${ }^{\mathrm{b}}$, Joana Couto ${ }^{\mathrm{a}}$, \\ Patrícia M. Évora ${ }^{\mathrm{b}}$, Catarina Rosa ${ }^{\mathrm{a}}$, Marcos R. Andréb ${ }^{\mathrm{b}}$, Rosângela Z. Machado ${ }^{\mathrm{b}}$, \\ Gervásio H. Bechara ${ }^{\mathrm{d}}$, Ana Domingos ${ }^{\mathrm{a}, \mathrm{c}, *}$ \\ a Instituto de Higiene e Medicina Tropical, Universidade Nova de Lisboa (IHMT-UNL), Rua da Junqueira 100, 1349-008 Lisboa, Portugal \\ ${ }^{\mathrm{b}}$ Universidade Estadual Paulista (FCAV-UNESP), Departamento de Patologia Veterinária, Jaboticabal, Via de Acesso Paulo Donato Castellane, s/n, \\ 14884-900 SP, Brazil \\ ' Global Health and Tropical Medicine, Instituto de Higiene e Medicina Tropical, Universidade Nova de Lisboa (GHTM-IHMT-UNL), Rua da Junqueira, 100, \\ 1349-008 Lisboa, Portugal \\ d Escola de Ciências da Vida, Pontifícia Universidade Católica do Paraná, Rua Imaculada Conceição, 1155, 80215-901 Curitiba, PR, Brazil
}

\section{A R T I C L E I N F O}

\section{Article history:}

Received 9 June 2016

Received in revised form 24 October 2016

Accepted 27 October 2016

Available online 29 October 2016

\section{Keywords:}

Rhipicephalus sanguineus s.l

RNAi

Ovaries

Oogenesis

ferritin 1

Ehrlichia canis

\begin{abstract}
A B S T R A C T
Rhipicephalus sanguineus sensu lato (s.l.) is a very common ectoparasite of domestic dogs able to transmit several pathogens of human and veterinary importance. Tick infestations and tick-borne diseases (TBDs) remain a serious and persistent problem, due to the lack of efficient control measures. It is therefore vital that novel approaches to control are pursued. Whilst vaccination is recognised as a potential control method to reduce tick infestation, no anti-R. sanguineus vaccine is available. Ticks depend on their blood meals to obtain nutrients and to achieve sexual maturity, which exposes them to vast amounts of iron. Although an essential molecule for several biological processes, its excess can lead to oxidative stress. Iron homeostasis is achieved with the help of iron-binding proteins called ferritins, among others, present in several tick tissues and developmental stages. These evolutionarily conserved proteins regulate iron homeostasis by storing and releasing iron in a controlled manner. In this study the R. sanguineus ferritin 1 gene was silenced through RNA interference (RNAi) in adult females exposed to an experimental infection with Ehrlichia canis. The purpose of this study was to assess the role of this protein in tick feeding, ovary development, oogenesis, and pathogen acquisition. Our data has shown that silencing ferritin 1 alters tick competence to normally engorge and causes morphologic and histochemical changes in the ovaries (OV) and oocytes. Furthermore, our data revealed that no E. canis DNA was found in either experimental group. Determining the function of molecules that act in key biological processes, such as blood digestion or reproduction, and that could be considered potential tick antigens will contribute towards the improvement of current control measures against these ectoparasites and the pathogens they vector.
\end{abstract} (C) 2016 Elsevier $\mathrm{GmbH}$. All rights reserved.

\section{Introduction}

Rhipicephalus sanguineus s.l. is a very common ectoparasite of domestic dogs (Dantas-Torres, 2008) and the most widespread

\footnotetext{
* Corresponding author at: Instituto de Higiene e Medicina Tropical, Universidade Nova de Lisboa (IHMT-UNL), Rua da Junqueira 100, 1349-008 Lisboa, Portugal.

E-mail addresses: joana.ferrolho@ihmt.unl.pt (J. Ferrolho),

santunes@ihmt.unl.pt (S. Antunes), GustavoSeron@hotmail.com (G.S. Sanches), jmanuel.couto@ihmt.unl.pt (J. Couto),patievora@hotmail.com

(P.M. Évora), catarinamsilvarosa@gmail.com (C. Rosa),

marcos_andre@fcav.unesp.br (M.R. André), zacarias@fcav.unesp.br (R.Z. Machado), gervasio.bechara@pucpr.br (G.H. Bechara), adomingos@ihmt.unl.pt (A. Domingos).
}

tick in the world, being particularly prevalent in tropical and subtropical regions (Aguirre et al., 2004; Dantas-Torres, 2010; Estrada-Pena and Jongejan, 1999; Hua et al., 2000; Keefe et al., 1982; Woldehiwet and Ristic, 1993) Considered a monotropic tick, all stages of $R$. sanguineus s.l. prefer dogs as primary hosts in both urban and rural areas, even though they could feed on other wild and domestic animals (Dantas-Torres, 2010). Immature stages can occasionally be found on rodents and other small mammals such as rabbits, cats, pigeons, wild canids and humans; whereas adults prefer larger mammals (Bouloy et al., 1994; Breitschwerdt et al., 2002; Maxwell, 2006). R. sanguineus s.l. is known to act as the vector of several infectious pathogens, including $E$. canis, the 
etiological agent of canine monocytic ehrlichiosis (CME) (Ewing, 1969; Groves et al., 1975; Harvey et al., 1979), Babesia canis (Regendanz and Muniz, 1936) and B. gibsoni (Sen, 1933), the agents of canine babesiosis, and of Coxiella burneti, the agent of Q fever (Mantovani and Benazzi, 1953), Hepatozoon canis, the agent of canine hepatozoonosis (Nordgren and Craig, 1984), Rickettsia conorii, responsible for Mediterranean spotted fever (Brumpt, 1932) and $R$. rickettsii, the agent of Rocky Mountain spotted fever (Parker et al., 1933). Recently, it has been suspected that $R$. sanguineus s.l. could also be involved in the transmission of Leishmania infantum, the etiological agent of visceral leishmaniasis (Coutinho et al., 2005).

Current methods of controlling ticks and TBDs rely heavily on chemical acaricides; however, their continued use is unsustainable not only due to environmental contamination but also due to the emergence of resistance caused by their intense and indiscriminate use, that most likely has selected tick populations with mutations in the genes that encode detoxifying enzymes; or that suffered genetic drift (Ghosh et al., 2007; Rodriguez-Vivas et al., 2011; Rosario-Cruz et al., 2009). Alternative cost-effective and environmentally friendly control measures such as anti-tick vaccines are urgently needed. The use of vaccines to reduce tick infestations is a well-established concept. The lack of highly efficacious antigens, however, remains a major limitation to developing vaccines that induce protective immune responses whilst preventing pathogen transmission (de la Fuente and Kocan, 2006). To date, no specific anti- $R$. sanguineus vaccine has been commercially developed.

Ticks are obligatory blood-sucking arthropods that depend completely on their hosts to obtain nutrients and, in the case of adult females, to achieve sexual maturity (Galay et al., 2013). During each blood meal, ticks are exposed to iron molecules that are required as biological cofactors for metabolic and transport functions, amongst others. At the same time, the excess of iron derived from the host blood can act as a highly toxic precursor of reactive oxygen species through the catalysis, propagation and production of reactive radicals (Wang and Pantopoulos, 2011). It also seems that ticks lack an efficient system to excrete iron through the faeces (Sonenshine, 1991). To prevent the oxidative damage to proteins, lipids and DNA caused by excess iron, and to establish iron homeostasis during a blood meal, ticks can store and metabolise these ions with the help of iron-binding ferritin proteins. These proteins are ubiquitously present in different tissues and at different developmental stages (Galay et al., 2013). An intracellular ferritin (FER1) that stores iron within cells, and a secretory type ferritin (FER2) that concentrates and secretes it from gut cells to the hemolymph, have been previously described in some hard ticks (Galay et al., 2013; Hajdusek et al., 2009). As antioxidants with different functions, both influence blood feeding, reproduction and survival, reinforcing the idea that these iron-binding proteins are strong candidates for further investigation for developing anti-tick antigens. Two recent studies have explored the ability of ferritins to elicit anti-tick immune responses. In rabbits immunised with two recombinant tick ferritins, one of these (H1FER2) offered some protection (Galay et al., 2014a). A similar study where cattle and rabbits were immunised with recombinant ferritins derived from different tick species, found the ferritin 2 (FER2) protein conferred some protection in both mammals (Hajdusek et al., 2010). These studies demonstrate the characterisation of highly conserved, fundamentally important proteins, such as ferritins, could contribute towards the improvement of current control measures.

In this study, RNAi experiments were conducted in $R$. sanguineus s.l. adult females fed on an E. canis-infected dog to evaluate the biological importance of ferritin 1 in tick feeding, ovary development, oogenesis, and pathogen acquisition.

\section{Material and methods}

\subsection{Ticks and bacteria}

The laboratory pathogen-free colony of $R$. sanguineus s.l. ticks (Tropical lineage)(GenBank no. KC018070 and JX997391)(Sanches, 2013; Sanches et al., 2012) was maintained at the Department of Veterinary Pathology, FCAV-UNESP, Jaboticabal, Brazil. Briefly, ticks were kept in a chamber regulated at $27 \pm 1^{\circ} \mathrm{C}, 80 \%$ relative humidity and a photoperiod of 12:12 (light: dark), and maintained by feeding on the ears of 5-8 month-old New Zealand white rabbits. For clarification, the tropical lineage of $R$. sanguineus, but not the temperate lineage, has been shown to be a competent vector of $E$. canis (Moraes-Filho et al., 2015).

E. canis Jaboticabal strain (GenBank no. DQ401044) was isolated from a Weimaraner dog blood sample during the acute phase of CME infection, in 1993 (Rosângela Z. Machado; unpublished data). Currently, the strain is maintained in the canine monocyte-macrophage cell line DH82 (Wellman et al., 1988) at the Immunoparasitology Laboratory, UNESP, Jaboticabal, São Paulo, as described elsewhere (Aguiar et al., 2007a,b).

\subsection{Experimental animals}

A two month-old male German shepherd dog was acquired from a certified breeder andconfirmed to be ehrlichiosis and ectoparasite-free. As an additional measure, $5 \mathrm{~mL}$ of blood were taken and tested for the presence of Neospora caninum (Mineo et al., 2009), Toxoplasma gondii (Domingues et al., 1998), E. canis (Andre et al., 2010) and B. vogeli (Furuta et al., 2009) by Indirect Fluorescent Antibody Test (IFAT), as previously described. Blood was also tested for the presence of E. canis (Murphy et al., 1998) and B. vogeli (Jefferies et al., 2007) by PCR. For the template, genomic DNA was extracted from whole blood using the DNeasy Blood \& Tissue Kit (Qiagen, Hilden, Germany), according to the manufacturer's instructions. All of these tests were negative. The animal was also vaccinated with Vanguard Plus $5^{\circledR}$ (Zoetis, New Jersey, USA) and RecombiteK C6/CV ${ }^{\circledR}$ (Merial, Georgia, USA), with a 3-week interval, and dewormed. Dry food was provided twice a day and water ad libitum. For the infection, the dog was inoculated intravenously with a dose of $4.5 \mathrm{~mL}$. canis purified from DH82 cells as described elsewhere (Aguiar et al., 2007a,b). When the experimental infection took place, the dog was 5 months-old. Following inoculation, the infection was monitored by qPCR for the $d s b$ gene (Doyle et al., 2005) and Giemsa-stained blood smears throughout the whole experimental period to confirm the presence of $E$. canis in the dog. The qPCR was positive for $d s b$ transcripts from day 3 post-inoculation. To detect the presence of morulae in Giemsastained capillary blood smears by light microscopy (Olympus CX31, Olympus, Tokyo, Japan), blood was taken from the ear tip, up until parasitaemia was confirmed on day 17 post-inoculation. The experimental animals were treated following the approved guidelines from the Lei Arouca 11.794/08, in Brazil.

\section{3. dsRNA synthesis and RNA interference}

The ferritin 1 mRNA sequence (GenBank accession number: EZ406186.1) was obtained from a $R$. sanguineus s.l. salivary gland (SG) transcriptome database (Anatriello et al., 2010). Primers (Ferritin_T7_F/Ferritin_T7_R) were designed against this sequence to include the T7 promoter sequence (Table 1). Total RNA was extracted from $R$. sanguineus SG using TriReagent (Sigma-Aldrich, St. Louis, USA) according to the manufacturer's instructions. cDNA was synthesised from 100 nanograms (ng) of total RNA using the iScript cDNA Synthesis Kit (Bio-Rad, California, USA) following the manufacturer's protocol. Using the aforementioned primer set, PCR 
Table 1

Primers sets for dsRNA synthesis and qPCR amplification.

\begin{tabular}{|c|c|c|c|c|c|}
\hline & Designation & Primer sequence & Product size (bp) & Final concentration $(\mu \mathrm{M})$ & Annealing temperature $\left({ }^{\circ} \mathrm{C}\right)$ \\
\hline \multirow{7}{*}{$\begin{array}{l}\text { dsRNA } \\
\text { synthesis }\end{array}$} & Ferritin_T7_F & 5'-ACGCGAGCTACGTCTACACA ${ }^{\mathrm{a}}-3^{\prime}$ & 353 & - & 55 \\
\hline & Ferritin_T7_R & 5'-CTTGATTGCCTTCACCTGCT ${ }^{\mathrm{a}}-\mathbf{3}^{\prime}$ & & & \\
\hline & ferritin_F & 5'-CAGCCGATACAGAAGCCATC-3' & 125 & 0.2 & $61.7^{b}$ \\
\hline & & & & & $58.2^{\mathrm{c}}$ \\
\hline & ferritin_R & 5'-TGATCGGTTGCCAACTTGTG-3' & & 0.2 & $61.7^{\mathrm{b}}$ \\
\hline & & & & & $58.2^{c}$ \\
\hline & Tick_16S_F & 5'-GACAAGAAGACCCTA-3' & Zivkovic et al. (2010) & 0.8 & 57.2 \\
\hline \multirow{7}{*}{ qPCR } & Tick_16S_R & 5'-ATCCAACATCGAGGT-3' & & 0.8 & 57.2 \\
\hline & $\beta$-actin_F & 5'-GACATCAAGGAGAAGCTYTGC-3' & Nijhof et al. (2009) & 0.8 & 58 \\
\hline & $\beta$-actin_R & 5'-CGTTGCCGATGGTGATS-3' & & 0.8 & 58 \\
\hline & $\beta$-tubulin_F & 5'-AACATGGTGCCCTTCCCACG-3' & & 0.4 & 58 \\
\hline & $\beta$-tubulin_R & 5'-GCAGCCATCATGTTCTTTGC-3' & & 0.4 & 58 \\
\hline & $E L F_{-} F$ & 5'-CGTCTACAAGATTGGTGGCATT-3' & & 0.4 & 57.2 \\
\hline & $E L F \_\mathrm{R}$ & 5'-CTCAGTGGTCAGGTTGGCAG-3' & & 0.4 & 57.2 \\
\hline
\end{tabular}

\footnotetext{
a T7 promotor sequence: 5'-taatacgactcactatagggaga-3'.

b Annealing temperature used for the samples of the salivary glands.

c Annealing temperature used for the samples of the midgut.
}

was performed in a $25 \mu \mathrm{L}$ reaction with Supreme NZYTaq 2x Green Master Mix (NZYTech, Lisbon, Portugal), $0.5 \mu \mathrm{M}$ primers, $2 \mu \mathrm{L}$ cDNA and nuclease-free water to the final volume. A no template negative control was also prepared. Amplification was performed in a T100 thermal cycler (Bio-Rad, CA, USA) with a thermal cycling profile of $95^{\circ} \mathrm{C}$ for $3 \mathrm{~min}$, and 40 cycles of $95^{\circ} \mathrm{C}$ for $30 \mathrm{~s}, 55^{\circ} \mathrm{C}$ for $30 \mathrm{~s}$ and $72^{\circ} \mathrm{C}$ for $60 \mathrm{~s}$, followed by a $72^{\circ} \mathrm{C}$ final extension for 5 min and a $4{ }^{\circ} \mathrm{C}$ hold. PCR products were separated on a $1.2 \%$ agarose (NZYTech, Lisbon, Portugal) gel $(\mathrm{w} / \mathrm{v})$ in $0.5 \mathrm{x}$ TBE buffer $(20 \mathrm{mM}$ Tris, $20 \mathrm{mM}$ boric acid, 0.5 mM EDTA, pH 7.2) stained with SybrSafe ${ }^{\mathrm{TM}}$ (Invitrogen, CA, USA) and examined by UV transillumination. The NZYDNA Ladder VIII DNA molecular weight marker (NZYTech, Lisbon, Portugal) was used to confirm the size of the products. The positive amplicon was purified using the NZYGelpure kit (NZYTech Lisbon, Portugal) and sequenced by the chain termination method at StabVida (Lisbon, Portugal). The sequence was aligned with other tick ferritin mRNA sequences from the NCBI nucleotide database (http://blast. ncbi.nlm.nih.gov/Blast) and the original sequence used for primer design. dsRNA synthesis was conducted using the MEGAscript T7 Kit (Ambion, California, USA) according to manufacturer's instructions. The product was visualised by agarose gel electrophoresis as described above. Seventeen days after E. canis inoculation, two tick feeding chambers were placed on the dog according to a previously described method (Bechara et al., 1995). Thirty adult females were injected with $0.2 \mu \mathrm{L}$ ferritin 1 dsRNA $\left(9.74 \times 10^{11}\right.$ molecules of dsRNA) between the coxa and trochanter I using a nanoinjector (Nanoject, Drummond Scientific, Broomall, PA, USA). The control group was injected with the same volume of elution buffer, similar to what has been described in other studies (Duscher et al., 2014; Hussein et al., 2015). Whilst the use of unrelated dsRNA is now a well-established control in species with full genome annotation, the $R$. sanguineus genome is poorly annotated, meaning inoculation with unconfirmed unrelated sequences can increase the off target effects in silencing experiments with this species.

Injected ticks were then left overnight in the regulated chamber. The next day, each group was placed into a feeding chamber, together with the same number of male ticks to stimulate cofeeding and copulation (Sanches et al., 2012) and allowed to feed until detachment. Engorged females were then collected, counted and weighed individually (mg). Immediately after, the SG, OV and midgut (MG) were dissected under an Olympus SZX7 stereo microscope (Olympus, Tokyo, Japan) in phosphate buffered saline (PBS) solution, $\mathrm{pH} 7.4$, at $4{ }^{\circ} \mathrm{C}$, and stored either in RNAlater (Ambion) at $-20^{\circ} \mathrm{C}$, for DNA/RNA extraction or the appropriate solutions for histological and histochemestry analysis.

\subsection{Extraction of total RNA and DNA}

SG and MG were transferred to TriReagent (Sigma-Aldrich, St Louis, USA) to extract total RNA and DNA and homogenized with a mortar and a pestle (VWR, Pennsylvania, USA). Extraction was carried out following the manufacturer's instructions. DNA concentration and purity was assessed by spectrophotometry using a NanoDrop ND-1000 (Thermo Fisher Scientific, Waltham, USA). In order to detect false negative results due to PCR inhibition and to validate the efficiency of DNA extraction, DNA was analysed in a T100 thermal cycler (Bio-Rad) by tick 18S rRNA amplification, as described previously (Shayan et al., 2007). RNA concentration and integrity were evaluated using an Agilent 2100 Bioanalyzer (Agilent Technologies Inc., Sta. Clara, USA). DNA was stored at $-20^{\circ} \mathrm{C}$ and RNA at $-80^{\circ} \mathrm{C}$, for downstream application.

\subsection{Efficiency of gene silencing}

The efficiency of ferritin 1 silencing was assessed in the SG and MG by qPCR using the minimum information for publication of qPCR experiments (Bustin et al., 2010). Data were normalised using $\beta$-actin, $\beta$-tubulin, 165 rDNA and elongation factor (ELF) as internal controls. Reference gene validation was based on the geNorm algorithm (Vandesompele et al., 2002) included in the CFX Manager ${ }^{\mathrm{TM}}$ Software (Bio-Rad, CA. USA) and on the expression stability value $M$ of each gene $(M<1)$. cDNA was synthesised using 300 ng RNA from each tick tissue with the iScript cDNA Synthesis Kit (BioRad, CA, USA). Table 1 shows the primer sets used for qPCR and their respective final concentrations and annealing temperatures. Briefly, triplicate $10 \mu \mathrm{L}$ reactions were prepared with $5 \mu \mathrm{L}_{\text {iTaq }}^{\mathrm{TM}}$ Universal SYBR ${ }^{\circledR}$ Green Supermix (Bio-Rad, CA, USA), $x \mu \mathrm{L}$ of each primer (see Table 1), $1 \mu \mathrm{L}$ cDNA and nuclease-free water to the final volume. Negative controls were prepared with no template. Standard curves were constructed with 10 -fold serial dilutions of a $R$. sanguineus s.l.cDNA to determine the reaction efficiency. The qPCR was carried out in a CFX96 Touch $^{\text {TM }}$ Real-Time PCR Detection System (Bio-Rad, CA, USA) with a thermal cycling profile of $95^{\circ} \mathrm{C}$ for $3 \mathrm{~min}$, and 40 cycles of $95^{\circ} \mathrm{C}$ for $10 \mathrm{~s}$ and $x^{\circ} \mathrm{C}$ (see Table 1 ) for $45 \mathrm{~s}$. To ensure that only one amplicon was formed, a melting curve was run at the end of every reaction $\left(55^{\circ} \mathrm{C}-95^{\circ} \mathrm{C} ; 0.5^{\circ} \mathrm{C} / \mathrm{s}\right.$ melt rates $)$. To confirm correct fragment amplification, gel electrophoresis was performed and fragments were sequenced at Stab Vida as described above. The CFX Manager ${ }^{\mathrm{TM}}$ Software (Bio-Rad, CA, USA) was used to analyse the gene expression data. 
Table 2

Evaluation of tick weight after ferritin 1-silencing in Rhipicephalus sanguineus ticks.

\begin{tabular}{|c|c|c|}
\hline Group $^{\mathrm{a}}$ & $\begin{array}{l}\text { Number of ticks completing } \\
\text { feeding }(\%)^{\mathrm{b}}\end{array}$ & $\begin{array}{l}\text { Weight after detachment } \\
(\text { mean } \pm \text { s.d.; } \mathrm{mg} / \text { tick })^{\mathrm{c}}\end{array}$ \\
\hline Control & $43.3(13)^{*}$ & $124.4 \pm 40.3$ \\
\hline Ferritin-silenced & $63.3(19)$ & $76.0 \pm 35.8^{* *}$ \\
\hline
\end{tabular}

\subsection{Ehrlichia canis detection in Rhipicephalus sanguineus s.l.} salivary glands

Quantitative PCR were carried out for the 16S rRNA of E. canis, following a previously described protocol (Peleg et al., 2010). Briefly, triplicate $10 \mu \mathrm{L}$ reactions were prepared with $5 \mu \mathrm{L} 2 \mathrm{x}$ PCR Mix SensiFast ${ }^{\circledR}$ Probe Low-Rox (Bioline, London, UK), $0.2 \mu \mathrm{M}$ of each primer, $0.2 \mu \mathrm{M}$ TaqMan Probe, $100 \mathrm{ng}$ DNA and nuclease-free water to the final volume. qPCR was carried out with a thermal cycling profile of $95^{\circ} \mathrm{C}$ for $15 \mathrm{~min}$, and 45 cycles of $93^{\circ} \mathrm{C}$ for $10 \mathrm{~s}$ and $61^{\circ} \mathrm{C}$ for $30 \mathrm{~s}$ (Bio-Rad). Negative controls were prepared with no template. Positive controls were prepared with E. canis Jaboticabal strain purified DNA. A standard curve was constructed with 10 -fold serial dilutions of the positive control DNA to determine reaction efficiency.

\subsection{Statistical analysis}

Weights of engorged females were compared by Student's $t$ test with unequal variance $(P=0.05)$ (statistical package in Excel 2013, Microsoft). Gene expression in the SG and MG was analysed by the CFX Manager ${ }^{\mathrm{TM}}$ Software (Bio-Rad, CA, USA). To analyse tick mortality, the Chi-square test $(P=0.05)$ was used with the null hypothesis that tick mortality and the capacity to complete feeding were not dependent on gene knockdown. Graphs were designed with GraphPad Instat ${ }^{\circledR}$, version 3.06, GraphPad Software, Inc. (San Diego, CA, USA).

\subsection{Ultrastructural characterisation, histological and histochemistry analysis of the ovaries after RNAi}

For the ultrastructural characterisation, the OV dissected from three fully engorged females of the control and ferritin-silenced groups were fixed in Karnovsky solution for $24 \mathrm{~h}$. Next, specimens were dehydrated through an acetone series (50\%, 75\%, 90\%, 95\% and $100 \%$ ) of 5 min each. The material was then processed using the critical point drying technique, sputtered with gold, examined and photographed using a HITASHI TM 3030 scanning electron microscope (SEM) (Hitachi High-Technologies, Tokyo, Japan). For the histological and histochemistry analysis, the OV of five fully engorged females were collected from each group (control and ferritin 1-silenced) to perform an oogenesis and vitellogenesis comparison. The OV were dissected and fixed in $4 \%$ paraformaldehyde for $24 \mathrm{~h}$, dehydrated for $30 \mathrm{~min}$ in an ethanol series $(70 \%, 80 \%, 90 \%$ and $100 \%$ ), embedded in Technovit 7100 solution A from the Technovit 7100 historesin kit (Heraeus Kulzer, Germany) for $24 \mathrm{~h}$ at $4{ }^{\circ} \mathrm{C}$, and transferred to plastic molds previously filled with glycol methacrylate containing a catalyst, according to manufacturers' instructions. After resin polymerization, the material was fixed on wood blocks. Serial sections of $3 \mu \mathrm{m}$ thickness were cut using a Sorvall JB4 microtome (Bio-Rad, CA. USA). Finally, the sections were stained with haematoxylin and eosin (H\&E), by following routine histological procedures; and histochemical tests were conducted to detect the presence of proteins (Bromophenol Blue according to Pearse, 1985) and lipids (Nile Blue according to Lison, 1960). The stained sections were observed and photographed under an Olympus CX31 light microscope (Olympus, Tokyo, Japan) coupled with a digital camera and Cell Sense Standard CS-ST 111 software (Olympus, Tokyo, Japan).

\section{Results}

\subsection{Ferritin 1 silencing efficiency in the salivary glands and midgut}

The obtained DNA fragment used for dsRNA synthesis was sequenced and compared with available sequences of ferritin 1 and ferritin 2 from other ticks species. The amplicon only showed identity to related ferritin 1 sequences, validating the gene specific silencing. Using qPCR, we confirmed gene knockdown after dsRNAmediated RNAi ferritin 1 gene silencing in the SG and MG, with 33.6\% and $43.6 \%$ reduction in expression levels, respectively (Fig. 1). Statistically significant differences were not found in the expression levels when compared with the control group $(P>0.05 ; 0.058$ for the SG and 0.875 for the MG).

\subsection{Evaluation of tick weight after RNAi}

The importance of ferritin 1 on tick engorgement was evaluated after gene silencing by RNAi. After drop-off, ticks were collected with survival and weight recorded up until 9 days post-infestation, at which point the remaining two attached ticks in the control group were manually removed. Table 2 shows the number of ticks that completed feeding on the E. canis-infected dog and the average weight. Both tick ability to complete feeding, recognised herein as natural drop-off, and tick mortality were not affected in dsRNA-injected ticks when compared with controls. Thus the null hypothesis was accepted $(P>0.05)$, suggesting that, for the level of silencing we attained, ferritin 1 does not affect tick survival. By contrast, the average body weight was statistically significantly higher in the control group $(124.4 \mathrm{mg} \pm 40.3)$ than that of the ferritin 1silenced group $(76.0 \pm 35.8)(p<0.05 ; 0.0013)$, demonstrating an effect of ferritin 1 on the feeding process.

\subsection{Impact of ferritin 1 silencing on tick ovaries and oocyte development}

Both groups presented a unique ovary with a tubular shape, with numerous oocytes of different sizes and stages of development (Fig. 2). The OV of the control group (Fig. 2A-C) presented more oocytes at a more advanced stage of development. The ferritin 1-silenced group (Fig. 2D-F) presented mature oocytes; however, their appearance suggested they were undergoing a degenerative and/or reabsorption process not observed in the controls (Fig. 2F).

A morpho-histological comparison between the OV of control female $R$. sanguineus s.l. and the OV of females from the ferritin 1- 


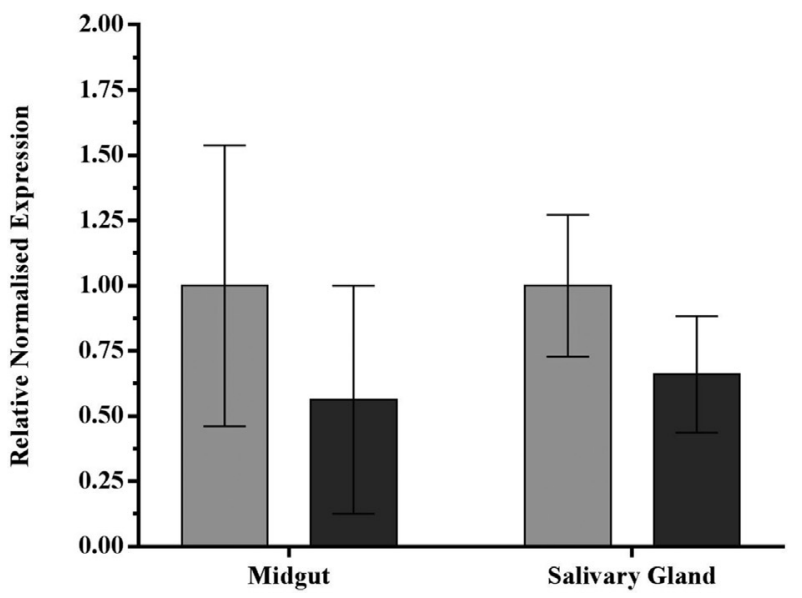

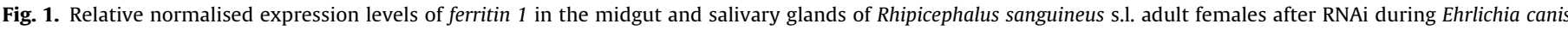
experimental infection.
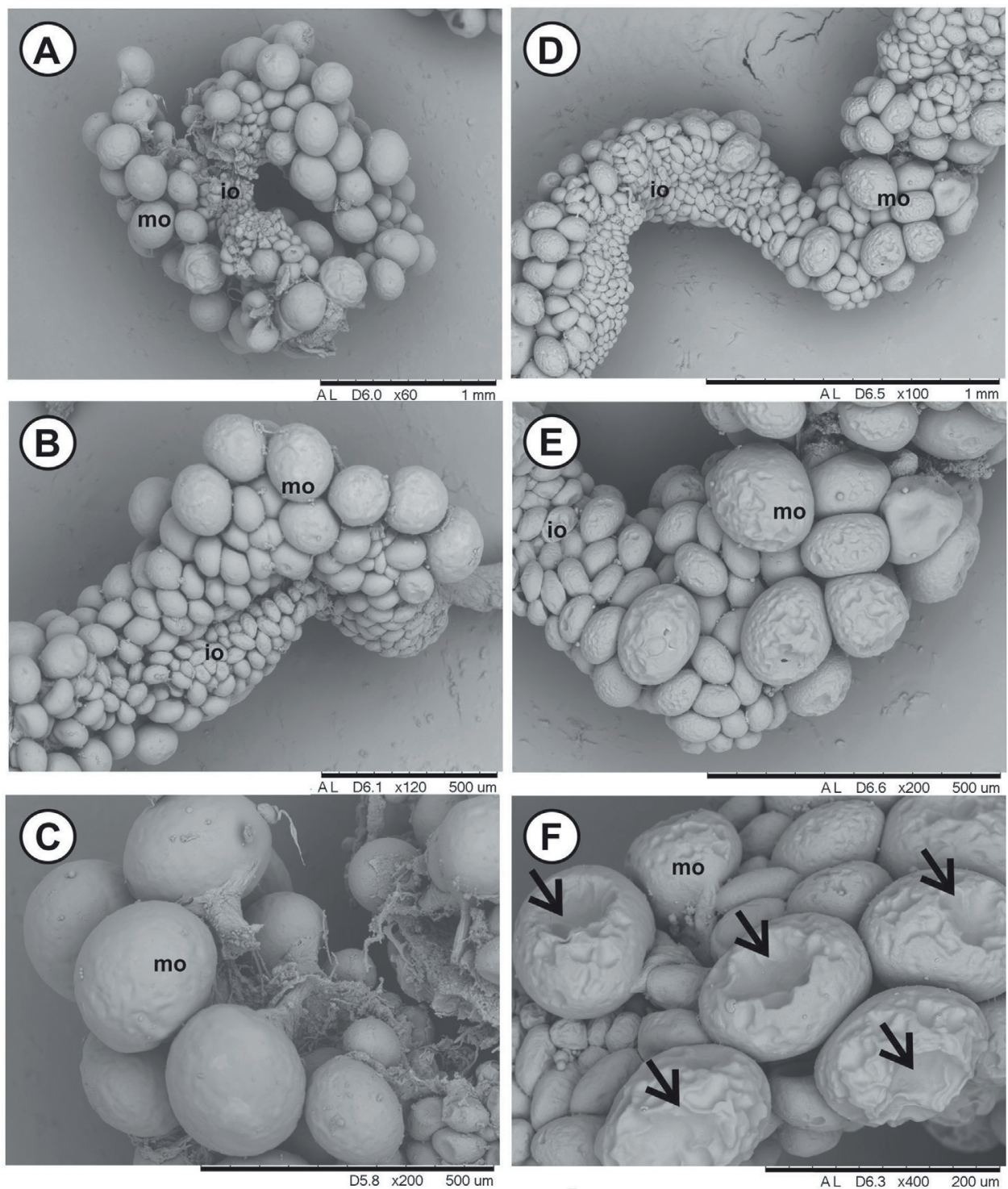

Fig. 2. Scanning electron micrographs of Rhipicephalus sanguineus s.l. ovaries from females of the control group (A-C) and of the group subjected to ferritin 1- silencing (D-F). A and B. General view of ovary from females belonging to the control group showing large amounts of mature oocytes. D and E. General view of ovary from females belonging to the ferritin 1-silenced group showing large amounts of immature oocytes. C. Detail of mature oocytes from an ovary belonging to the control group. F. Detail of mature oocytes from an ovary belonging to the ferritin 1-silenced group in reabsorption process (arrowed). Scale bars: $A, D=1000 \mu \mathrm{m} ; B, C, E=500 \mu \mathrm{m} ; \mathrm{F}=200 \mu \mathrm{m}$. 

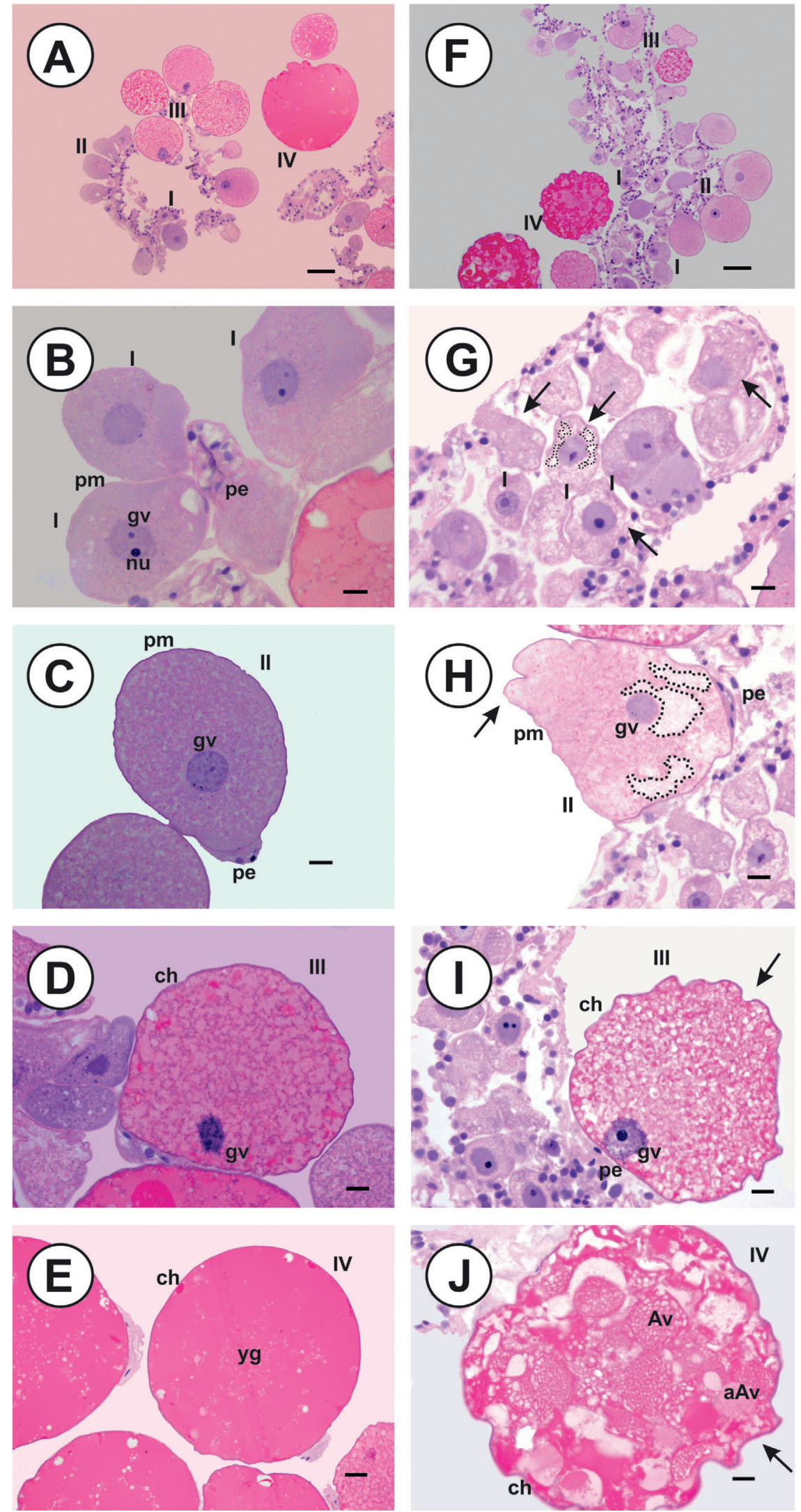

Fig. 3. Histological sections of Rhipicephalus sanguineus s.l. ovaries from females of the control group (A-E) and of the group subjected to ferritin 1-silencing (F-J) stained by

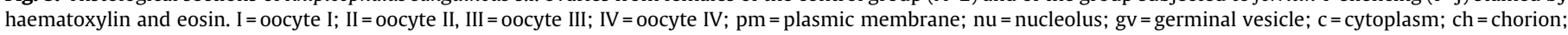
$\mathrm{yg}=$ yolk granules; $\mathrm{Av}=$ autophagic vesicle; $\mathrm{a} A \mathrm{v}=$ autophagic vesicle in advanced digestion stage; vacuolated area delimited by dotted line; irregular shape arrowed. Scale bars: A, F=100 $\mu \mathrm{m} ; \mathrm{B}, \mathrm{C}, \mathrm{D}, \mathrm{E}, \mathrm{H}, \mathrm{I}, J=20 \mu \mathrm{m} ; \mathrm{G}=50 \mu \mathrm{m}$;. 


\section{Control}
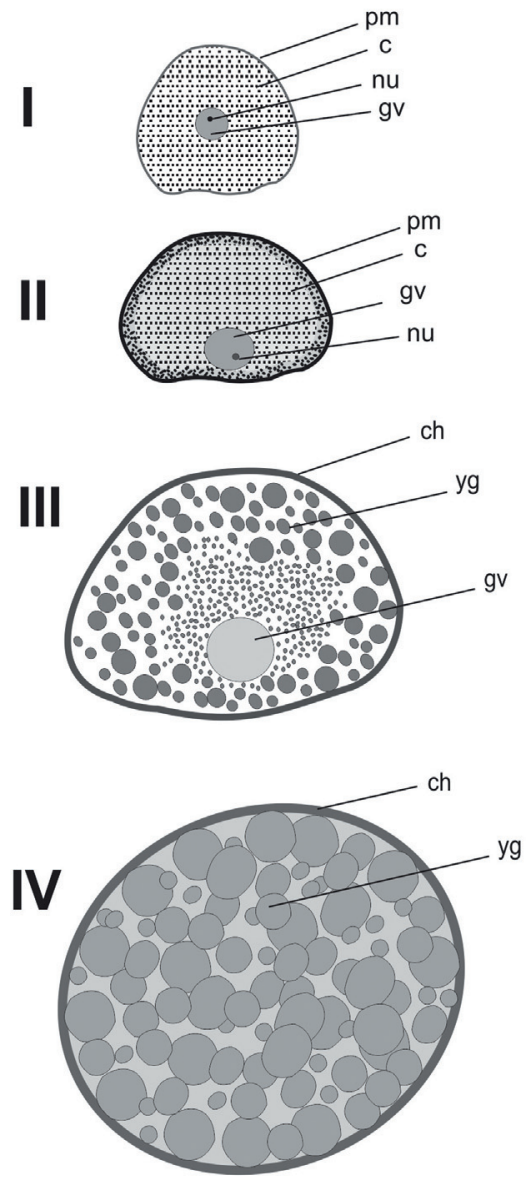

Ferritin
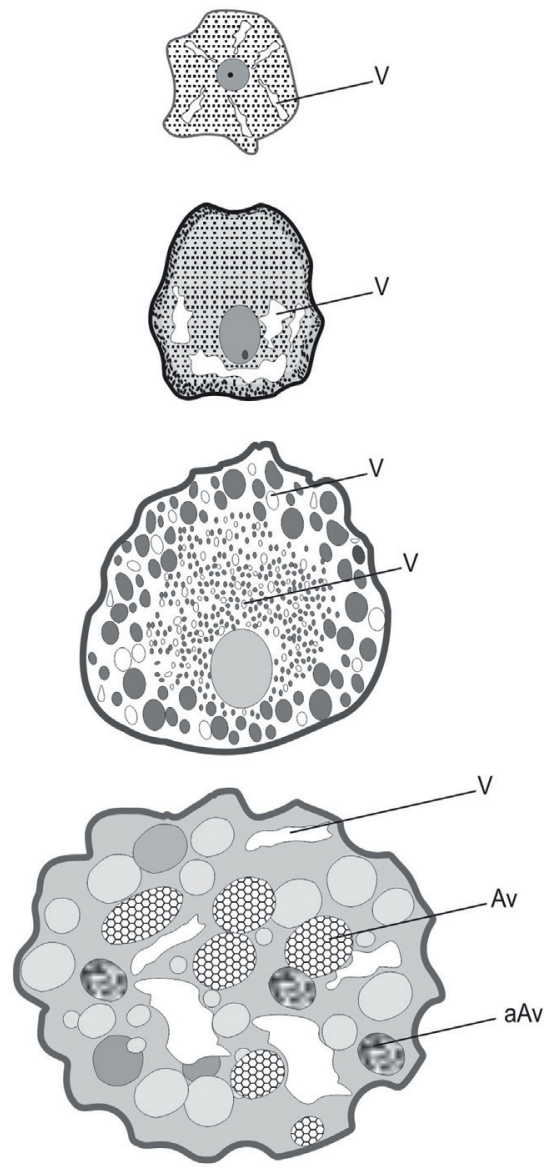

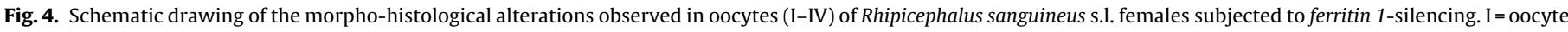

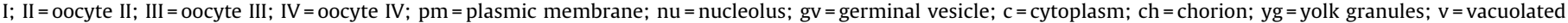
area; $\mathrm{Av}=$ autophagic vesicle; $\mathrm{aAv}=$ autophagic vesicle in advanced digestion stage.

silenced group are presented in Fig. 3. These changes have been summarised in Fig. 3. The control group presented OV consisting of a single tubular structure composed of epithelial cells with rounded nuclei forming the ovarian wall with oocytes of different developmental stages attached externally to this wall by the pedicel (Fig. 3A and B). The morphology the previtellogenic oocytes (stage I and II) showed a homogeneous cytoplasm containing fine granulation with an evident germ vesicle in the centre (Fig. 3B and C). Oocytes III (vitellogenic oocytes) displayed a cytoplasm with yolk granules of various sizes and the germ vesicle occupied the oocytesí pole facing the pedicel. The plasma membrane appeared thick and the chorion had begun to form (Fig. 3D). Oocytes IV were large and rounded, with great yolk granulation and with the chorion almost totally deposited (Fig. 3E). Oocytes $\mathrm{V}$ were rarely found in the two groups because ticks were dissected immediately after detachment, preventing the complete maturation of large numbers of oocytes. In the ferritin 1-silenced group, the OV exhibited larger amounts of oocytes in early stages of development than in the control group (Fig. $3 \mathrm{~A}$ and F). The cells of the pedicel have shown several morphological alterations, such as loss of nuclei, loss of cell contact, decreased cell numbers forming the pedicel and nucleated cells located in lateral areas (Fig. $3 \mathrm{H}$ and I). Oocytes I (Figs. 3G and 4I) had an irregular shape and vacuolated cytoplasm, with the vacuoles located near the marginal region. Furthermore, the ferritin 1-silenced group oocytes II showed pronounced alterations in shape. The cytoplasmic vacuolization process was frequent with vacuoles occupying the marginal region and the area around the germinal vesicle (Fig. 3H). Oocytes III exhibited cellular contour with folds and deformations along their entire length. The cytoplasm was heterogeneous in appearance, with a different distribution pattern of yolk granules. The yolk granules were distributed throughout the cytoplasm, permeated by small areas of homogeneously distributed vacuolization (Figs. 3I and 4III ). Oocytes IV (Figs. 3J and 4IV) showed a loss of cellular contour, with folds and deformations along the entire length of the chorion. Autophagic vesicles were distributed throughout the cytoplasm.

Histochemical analysis revealed that both groups of oocytes reacted positively to the Bromophenol Blue for protein detection. In the control group, oocytes I (Fig. 5A) and oocytes II (Fig. 5B) had cytoplasm slightly and homogeneously stained, with the germ vesicle nucleolus moderately positive. Oocytes II exhibited a fine positive granulation distributed throughout the cytoplasm, with peripheral areas moderately stained. Oocytes III (Fig. 5C) had weakly stained cytoplasm, with small granulation in the centre while the surrounding areas presented more granulation, which was moderately stained. Oocytes IV (Fig. 5D) had large moderately stained yolk granules, with small negatively stained rounded areas surrounding them. In the ferritin 1-silenced group, oocytes I (Fig. 5E) had the centre of the cytoplasm around the germ vesicle moderately stained, with peripheral areas weakly stained, and the germ vesicle nucleolus moderately positive. Oocytes II (Fig. 5F) exhibited a large area of fine positive granulation distributed only around the 

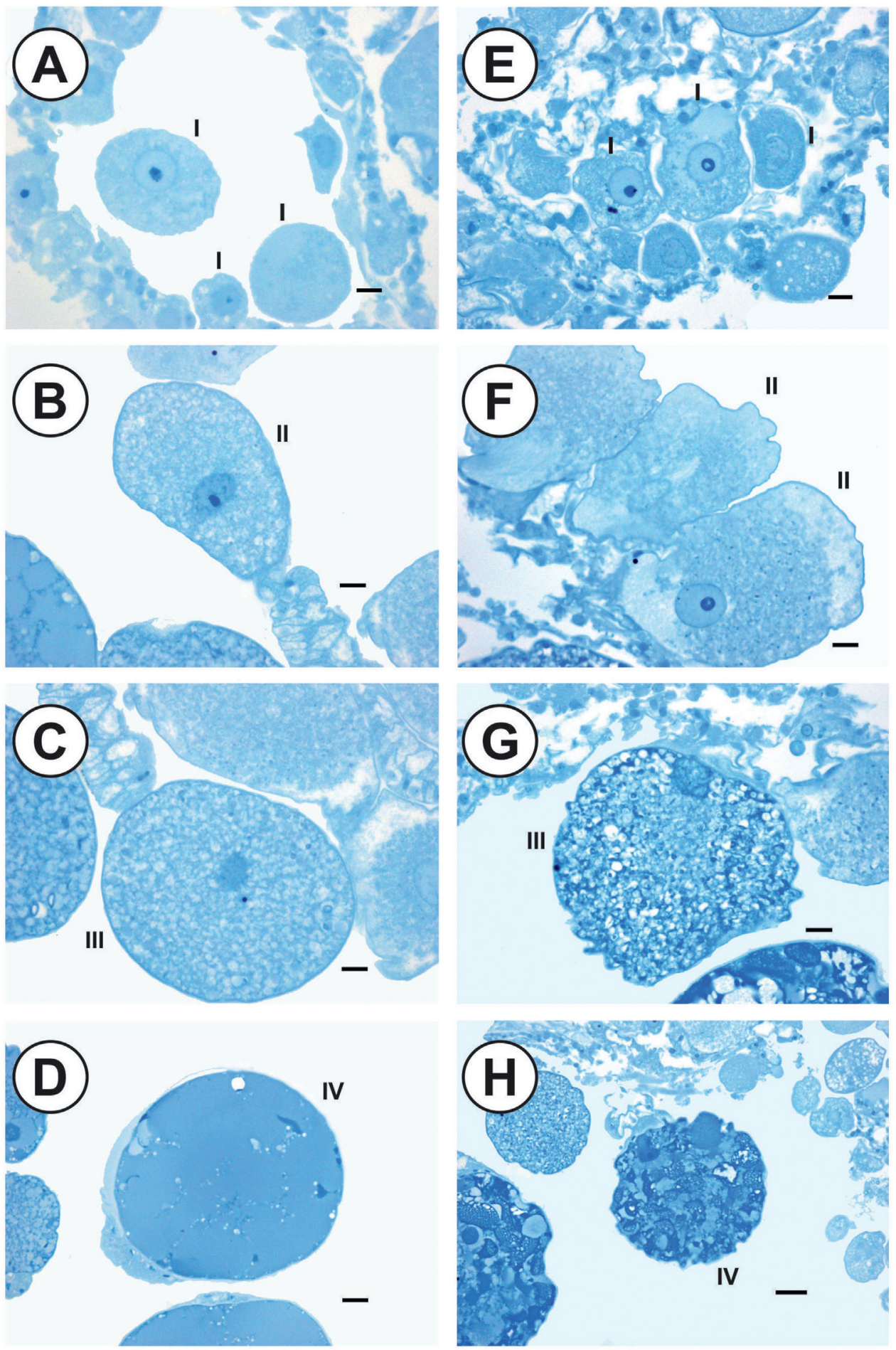

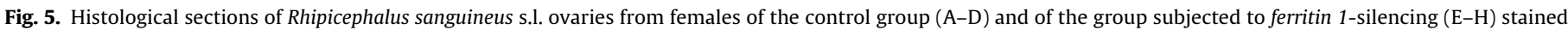
by Bromophenol Blue. I = oocyte I; II = oocyte II, III = oocyte III; IV= oocyte IV. Scale bars: A $-\mathrm{G}=20 \mu \mathrm{m} ; \mathrm{H}=50 \mu \mathrm{m}$;

germ vesicle, with negatively stained peripheral areas (vacuolated region). In the oocytes III (Fig. 5G), the cytoplasm was moderately stained, with small granulation at the central region, while the surrounding areas had more granulation, which was strongly stained. Oocytes IV (Fig. $5 \mathrm{H}$ ) were strongly stained inside the autophagic vesicles, with cytoplasmic areas weakly stained around these vesicles.

When staining with Nile Blue for lipid detection, the different developmental stages of the oocytes presented a normal pattern of dye affinity for lipids in the control group.
Oocytes I presented a homogeneous and strongly blue stained cytoplasm, indicating the presence of acid lipids (Fig. 6A). Oocytes II had a fine granulation, which was stained moderately blue and homogeneously distributed throughout the cytoplasm. This was accompanied by a fine granulation stained moderately pink, indicating the presence of neutral lipids (Fig. 6A). Oocytes III (Fig. 6B) had cytoplasm with small strongly stained yolk granules deposited in the centre, with some larger granules frequently found in the surroundings areas. Oocytes IV (Fig. 6C) had cytoplasm with large weakly stained blue granules, with some regions around these 


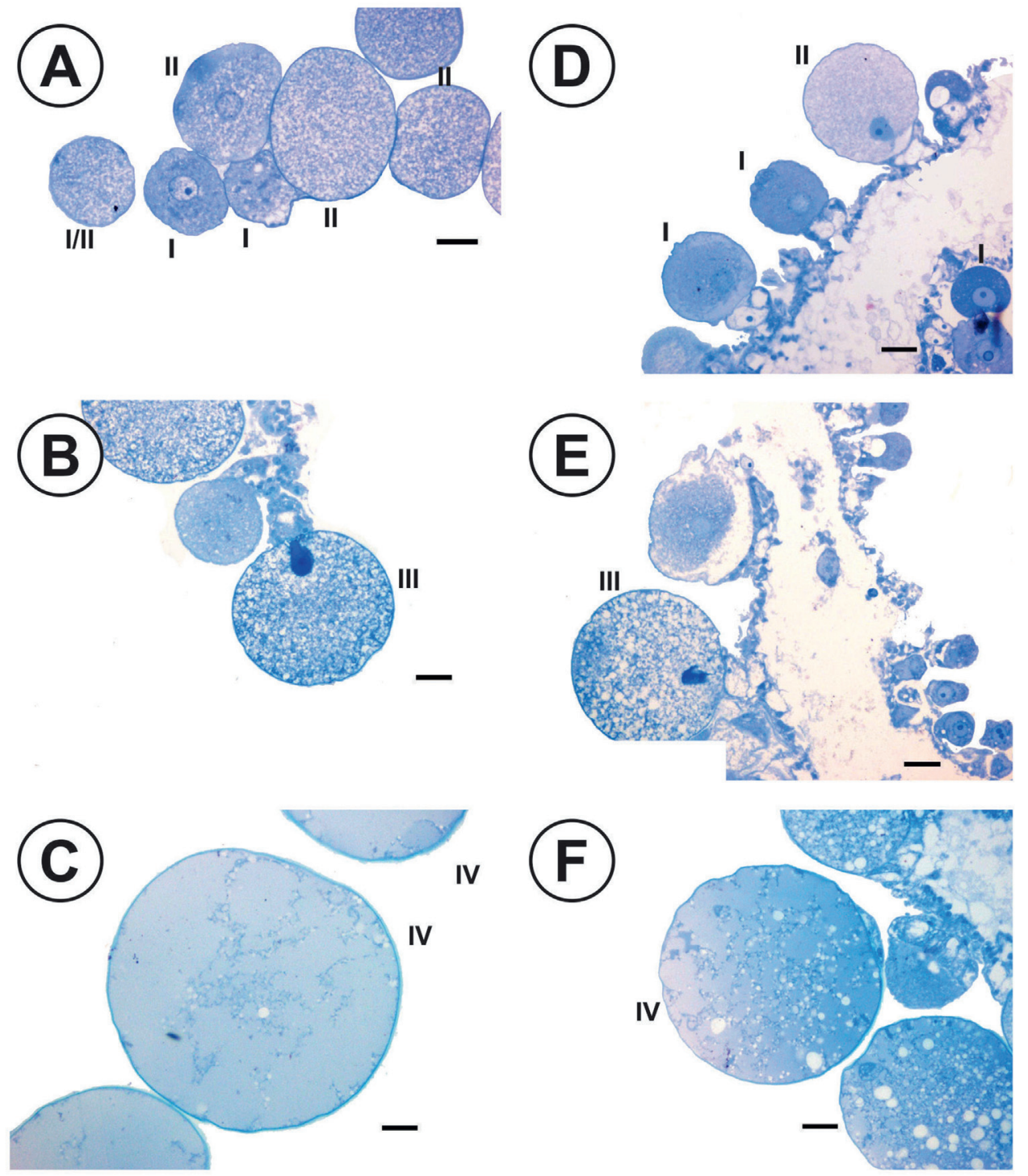

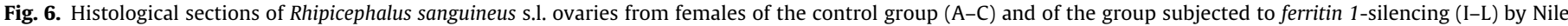
Blue. I = oocyte I; II = oocyte II; III = oocyte III; IV = oocyte IV. Scale bars: A, B, D, E=50 $\mu \mathrm{m}$; C, F = $20 \mu \mathrm{m}$.

granules also strongly stained blue, indicating that lipids could be forming complexes with other molecules (e.g. proteins) or in free form. Similarly, oocytes I (Fig. 6D) in the ferritin 1-silenced group presented a homogeneous and moderately to strongly blue stained cytoplasm, although peripheral areas were weakly stained blue. Oocytes II (Fig. 6D) had a different staining pattern when compared with the control group. The cytoplasm contained some fine weakly stained blue granulation in the centre and a lot of fine granulation, which was weakly stained pink. Oocytes III (Fig. 6E) presented the same pattern as oocytes I in the control group, but with less granulation in the centre. In oocytes IV (Fig. 6F), large weakly stained blue granules were observed in the region next to the pedicel and large weakly stained pink granules in the peripheral region. Some rounded areas appeared negatively stained in the cytoplasm.

\subsection{Ehrlichia canis quantification}

To evaluate whether the ferritin 1 knockdown plays a role in pathogen acquisition and multiplication, qPCR was carried out targeting the $16 \mathrm{~S}$ rRNA of E. canis in the SG. When testing the control group and the ferritin 1-silenced group, no E. canis DNA was detected preventing any further assessment of these factors (data not shown).

\section{Discussion}

The genes encoding ferritins have been identified in different tick species including Ixodes ricinus and the soft tick Ornithodoros moubata and the protein sequences were found to have high identity (Kopacek et al., 2003; Xu et al., 2004). Based on this information and on the fact that $R$. sanguineus s.l. is a tick of great medicalveterinarian importance, the present study investigated the effects of silencing ferritin 1 in ticks on the ability to feed, ovary and oocyte development and pathogen acquisition. Ferritin 1 is described as responsible for the intracellular storage of iron in digestive cells and the primary ferritin in MG cells with a vital cytoprotective role in the antioxidant response (Galay et al., 2013, 2014b). In the hard tick Haemaphysalis longicornis qPCR analysis of FER1 (Hlfer1) showed it is expressed in the MG, SG, hemocytes, fat body and OV during blood feeding. Using immunolocalisation, the native protein was found in the cytoplasm of MG digestive cells, in the salivary acini and salivary duct of the SG and in the oviduct and oocytes in the OV (Galay et al., 2013). 
The present study demonstrates that ferritin 1 knockdown resulted in a significant decrease in tick weight after detachment in comparison to the negative control, suggesting that their capability to feed or to attain full engorgement was altered. In this experiment no unrelated dsRNA was used, since to date $R$. sanguineus s.l. genome is not available to ensure complete disparity of sequence complementarity. Also, there is no evidence that unspecific dsRNA effects could lead to notorious effects on tick phenotype.

Although in our study only ferritin 1 was silenced, the overall results are similar to others previously reported for I. ricinus female ticks, in which the silencing of the genes encoding FER1, FER2 and the iron regulatory protein IRP1 had an adverse impact on feeding with consequent decrease in weight after the blood meal (Hajdusek et al., 2009). Results suggest that the reduction in tick feeding capacity, and thus to fully engorge, may be related to an imbalance in iron homeostasis and consequent iron accumulation, leading to toxicity. Moreover, Galay et al. (2013) observed that after Hlfer silencing, fewer digestive cells with hematin, one of the products of blood digestion, were present in the MG. This probably jeopardised the tick normal engorgement capacity by decreasing MG digestive activity. Under the conditions undertaken in this study, no significant effect on survival rate was observed in the silenced $R$. sanguineus s.l. ticks. Despite this, another study conducted in $H$. longicornis demonstrated the antioxidant protective role of ferritin promoted tick survival (Galay et al., 2014b).

For the perpetuation of any species, the role of the female reproductive system is crucial. In our study, adult females of $R$. sanguineus s.l. in which ferritin 1 was silenced presented morphologic changes in the oocytes and alterations in the dye affinity for lipids and proteins, not seen in the controls. Morphologically, the oocytes were less developed and those in a more advanced stage of maturation presented typical characteristics of degeneration and reabsorption, such as an irregular shape with folds and deformations, together with heterogeneous vacuolated cytoplasm and autophagic vesicles. Some authors have related the presence of autophagic vacuoles in cells with active processes of degradation and recycling in certain areas of the cytoplasm or organelles (Carvalho and Recco-Pimentel, 2012; Junqueira and Carneiro, 2013). According to the histochemical results for lipid and protein detection, in the control group it was observed that the yolk granulation was located in the central region as expected (de Oliveira et al., 2005); while in the ferritin-1 silenced group the granulation was extended from the central to the marginal region. The increase of vacuolation and different pattern and distribution of yolk granules in the oocytes might be related to the degradation of cell organelles with formation of autophagic vacuoles as a defence mechanism; but it might also reflect the fact that yolk production is happening at a slower rate or being impaired. Normally, during endogenous yolk production, smaller granules located mainly in the central region of oocytes III gradually fuse together becoming larger and moving towards the oocyte periphery (de Oliveira et al., 2005). The alterations detected in the present study and others suggest that a reduction in the normal gene expression levels of the iron-binding protein ferritin 1 might cause structural changes in $R$. sanguineus s.l. germ cells.

In the tick H. longicornis it was shown that when FER1 and FER2 genes were silenced, both tick feeding and reproductive capacity were greatly impaired (Galay et al., 2013). The same result of reduced weight and reduction in the number of eggs and hatched eggs was verified but was less profound when adult ticks ingested anti-HIFER 1 and 2 antibodies during a blood meal (Galay et al., 2014a); and when fer1 was silenced, with a reduction in oviposition and prevention of egg hatching (Hajdusek et al., 2009). Thus these studies suggest that iron storage is crucial for proper embryo development, without which the hatching of larvae does not occur. Lastly, the reduction in feeding among the silenced group might also have led to the difficulty in achieving the female Critical Weight
(CW; that corresponds to approximately $10 \mathrm{x}$ the unfed weight), a concept investigated by Weiss and Reuben Kaufman (2001), and consequently the difficulty in ovary maturation, with overall reduction of the size of the OV. In A. hebraeum, it is only when the critical weight is achieved that 20-hydroxyecdysone is synthesised for further vitellogenin production, required for ovary maturation (Weiss and Reuben Kaufman, 2001). Taken together, these results become interesting and promising under the perspective of controlling tick populations through reproductive blockage.

\section{Conclusions}

This study aimed to characterise the effects of ferritin 1-silencing using RNAi in tick feeding, OV and oocyte development, and pathogen acquisition in $R$. sanguineus s.l. Our study reinforced the importance of intracellular ferritin 1 on the capacity of ticks to engorge and to achieve reproductive maturity, which are closely related functions. This is the first study conducted in the hard tick $R$. sanguineus s.l. reporting a reduction in tick weight after detachment and abnormalities in the OV and oocyte morphology after ferritin 1 knockdown. Identification and functional characterisation of genes and proteins that are fundamentally important for maintaining physiological homeostasis will improve our understanding of vector biology and contribute towards the development of specific anti-tick vaccines. Moreover, the development and use of a vaccine that reduces tick feeding capacity, survival and fecundity would uncover new targets to disrupt the tick life cycle and disease transmission. The long-term aim being improvement of current control measures to reduce environmental tick populations, host tick infestations and TBDs.

\section{Conflict of interest}

The authors declare no competing personal or financial interests.

\section{Acknowledgments}

This work was supported by Fundação para a Ciência e Tecnologia (FCT), Portugal, and Coordenação de Aperfeiçoamento de Pessoal de Nível Superior (CAPES), Brazil, (Project 038/2013CAPES/FCT).

\section{References}

Aguiar, D.M., Saito, T.B., Hagiwara, M.K., Machado, R.Z., Labruna, M.B., 2007a. Serological diagnosis of canine monocytic ehrlichiosis with Brazilian antigen of Ehrlichia canis. Cienc. Rural 37 (3), 796-802.

Aguiar, D.M., Saito, T.B., Hagiwara, M.K., Machado, R.Z., Labruna, M.B., 2007b. Serological diagnosis of canine monocytic ehrlichiosis with Brazilian antigen of Ehrlichia canis. Cienc. Rural 37, 796-802.

Aguirre, E., Sainz, A., Dunner, S., Amusategui, I., Lopez, L., Rodriguez-Franco, F., Luaces, I., Cortes, O., Tesouro, M.A., 2004. First isolation and molecular characterization of Ehrlichia canis in Spain. Vet. Parasitol. 125, 365-372.

Anatriello, E., Ribeiro, J.M., de Miranda-Santos, I.K., Brandao, L.G., Anderson, J.M., Valenzuela, J.G., Maruyama, S.R., Silva, J.S., Ferreira, B.R., 2010. An insight into the sialotranscriptome of the brown dog tick, Rhipicephalus sanguineus. BMC Genom. 11, 450.

Andre, M.R., Adania, C.H., Machado, R.Z., Allegretti, S.M., Felippe, P.A., Silva, K.F., Nakaghi, A.C., 2010. Molecular and serologic detection of Ehrlichia spp. in endangered Brazilian wild captive felids. J. Wildl. Dis. 46, 1017-1023.

Bechara, G.H., Szabo, M.P., Ferreira, B.R., Garcia, M.V., 1995. Rhipicephalus sanguineus tick in Brazil: feeding and reproductive aspects under laboratorial conditions. Rev. Bras. Parasitol. Vet. 4, 61-66.

Bouloy, R.P., Lappin, M.R., Holland, C.H., Thrall, M.A., Baker, D., O’Neil, S., 1994. Clinical ehrlichiosis in a cat. J. Am. Vet. Med. Assoc. 204, 1475-1478.

Breitschwerdt, E.B., Abrams-Ogg, A.C., Lappin, M.R., Bienzle, D., Hancock, S.I., Cowan, S.M., Clooten, J.K., Hegarty, B.C., Hawkins, E.C., 2002. Molecular evidence supporting Ehrlichia canis-like infection in cats. J. Vet. Intern. Med. 16, 642-649.

Brumpt, E., 1932. Longevite du virus de la fievre boutonneuse chez la tique, Rhipicephalus sanguineus. C. R. Soc. Biol. 8, 1199-1202. 
Bustin, S.A., Beaulieu, J.F., Huggett, J., Jaggi, R., Kibenge, F.S., Olsvik, P.A., Penning, L.C., Toegel, S., 2010. MIQE precis: practical implementation of minimum standard guidelines for fluorescence-based quantitative real-time PCR experiments. BMC Mol. Biol. 11, 74.

Carvalho, H.F., Recco-Pimentel, S.M., 2012. A Célula. Editora Manole, São Paulo 3 Ed.

Coutinho, M.T., Bueno, L.L., Sterzik, A., Fujiwara, R.T., Botelho, J.R., De Maria, M., Genaro, O., Linardi, P.M., 2005. Participation of Rhipicephalus sanguineus (Acari: Ixodidae) in the epidemiology of canine visceral leishmaniasis. Vet. Parasitol. 128, 149-155.

de Oliveira, P.R., Bechara, G.H., Denardi, S.E., Nunes, E.T., Camargo Mathias, M.I., 2005. Morphological characterization of the ovary and oocytes vitellogenesis of the tick Rhipicephalus sanguineus (Latreille, 1806) (Acari: Ixodidae). Exp. Parasitol. 110, 146-156.

de la Fuente, J., Kocan, K.M., 2006. Strategies for development of vaccines for control of ixodid tick species. Parasite Immunol. 28, 275-283.

Dantas-Torres, F., 2008. The brown dog tick, Rhipicephalus sanguineus (Latreille, 1806) (Acari: Ixodidae): from taxonomy to control. Vet. Parasitol. 152, 173-185.

Dantas-Torres, F., 2010. Biology and ecology of the brown dog tick, Rhipicephalus sanguineus. Parasites Vectors 3, 26.

Domingues, L.M., Machado, R.Z., Costa, M.T., 1998. Canine toxoplasmosis: a comparative evaluation of the detection of anti-Toxoplasma gondii antibodies by the indirect immunoenzimatic assay (ELISA) and indirect immunofluorescent reaction (IIF). Braz. J. Vet. Parasitol. 4, 79-85.

Doyle, C.K., Cardenas, A.M., Aguiar, D.M., Labruna, M.B., Ndip, L.M., Yu, X.J., McBride, J.W., 2005. Molecular characterization of E. canis gp36 and $E$. chaffeensis gp47 tandem repeats among isolates from different geographic locations. Ann. N. Y. Acad. Sci. 1063, 433-435.

Duscher, G.G., Galindo, R.C., Tichy, A., Hummel, K., Kocan, K.M., de la Fuente, J., 2014. Glutathione S-transferase affects permethrin detoxification in the brown dog tick, Rhipicephalus sanguineus. Ticks Tick-Borne Dis. 5, 225-233.

Estrada-Pena, A., Jongejan, F., 1999. Ticks feeding on humans: a review of records on human-biting Ixodoidea with special reference to pathogen transmission. Exp. Appl. Acarol. 23, 685-715.

Ewing, S.A., 1969. Canine ehrlichiosis. Adv. Vet. Sci. Comp. Med. 13, 331-353.

Furuta, P.I., Oliveira, T.M., Theixeira, M.C., Rocha, A.G., Machado, R.Z., Tinucci-Costa, M.G., 2009. Comparison between a soluble antigen-based ELISA and IFAT in detecting antibodies against Babesia canis in dogs. Rev. Bras. Parasitol. Vet. 18, 41-45.

Galay, R.L., Aung, K.M., Umemiya-Shirafuji, R., Maeda, H., Matsuo, T., Kawaguchi, H., Miyoshi, N., Suzuki, H., Xuan, X., Mochizuki, M., Fujisaki, K., Tanaka, T., 2013. Multiple ferritins are vital to successful blood feeding and reproduction of the hard tick Haemaphysalis longicornis. J. Exp. Biol. 216, 1905-1915.

Galay, R.L., Miyata, T., Umemiya-Shirafuji, R., Maeda, H., Kusakisako, K., Tsuji, N., Mochizuki, M., Fujisaki, K., Tanaka, T., 2014a. Evaluation and comparison of the potential of two ferritins as anti-tick vaccines against Haemaphysalis longicornis. Parasites Vectors 7, 482.

Galay, R.L., Umemiya-Shirafuji, R., Bacolod, E.T., Maeda, H., Kusakisako, K., Koyama, J., Tsuji, N., Mochizuki, M., Fujisaki, K., Tanaka, T., 2014b. Two kinds of ferritin protect ixodid ticks from iron overload and consequent oxidative stress. PLoS One 9, e90661.

Ghosh, S., Azhahianambi, P., Yadav, M.P., 2007. Upcoming and future strategies of tick control: a review. J. Vector Borne Dis, 44, 79-89.

Groves, M.G., Dennis, G.L., Amyx, H.L., Huxsoll, D.L., 1975. Transmission of Ehrlichia canis to dogs by ticks (Rhipicephalus sanguineus). Am. J. Vet. Res. 36, 937-940.

Hajdusek, O., Sojka, D., Kopacek, P., Buresova, V., Franta, Z., Sauman, I., Winzerling, J., Grubhoffer, L., 2009. Knockdown of proteins involved in iron metabolism limits tick reproduction and development. Proc. Natl. Acad. Sci. U. S. A. 106, 1033-1038

Hajdusek, O., Almazan, C., Loosova, G., Villar, M., Canales, M., Grubhoffer, L., Kopacek, P., de la Fuente, J., 2010. Characterization of ferritin 2 for the control of tick infestations. Vaccine 28, 2993-2998.

Harvey, J.W., Simpson, C.F., Gaskin, J.M., Sameck, J.H., 1979. Ehrlichiosis in wolves, dogs, and wolf-dog crosses. J. Am. Vet. Med. Assoc. 175, 901-905.

Hua, P., Yuhai, M., Shide, T., Yang, S., Bohai, W., Xiangrui, C., 2000. Canine ehrlichiosis caused simultaneously by Ehrlichia canis and Ehrlichia platys. Microbiol. Immunol, 44, 737-739.

Hussein, H.E., Scoles, G.A., Ueti, M.W., Suarez, C.E., Adham, F.K., Guerrero, F.D., Bastos, R.G., 2015. Targeted silencing of the Aquaporin 2 gene of Rhipicephalus (Boophilus) microplus reduces tick fitness. Parasites Vectors 8, 618.

Jefferies, R., Ryan, U.M., Jardine, J., Broughton, D.K., Robertson, I.D., Irwin, P.J., 2007. Blood, bull terriers and babesiosis: further evidence for direct transmission of Babesia gibsoni in dogs. Aust. Vet. J. 85, 459-463.

Junqueira, L.C., Carneiro, J., 2013. Histologia Básica. Guanabara Koogan, Rio de Janeiro.

Keefe, T.J., Holland, C.J., Salyer, P.E., Ristic, M., 1982. Distribution of Ehrlichia canis among military working dogs in the world and selected civilian dogs in the United States. J. Am. Vet. Med. Assoc. 181, 236-238.
Kopacek, P., Zdychova, J., Yoshiga, T., Weise, C., Rudenko, N., Law, J.H., 2003. Molecular cloning, expression and isolation of ferritins from two tick species-ornithodoros moubata and Ixodes ricinus. Insect Biochem. Mol. Biol. 33, 103-113.

Mantovani, A., Benazzi, P., 1953. The isolation of Coxiella burnetii from Rhipicephalus sanguineus on naturally infected dogs. J. Am. Vet. Med. Assoc 122, 117-118.

Maxwell, O.I.C.O.C.G.O., 2006. Environmental and multi-host infestation of the brown dog tick, Rhipicephalus sanguineus in Owerri, South-east Nigeria- a case report. Vet. Arch. 76

Mineo, T.W., Carrasco, A.O., Marciano, J.A., Werther, K., Pinto, A.A., Machado, R.Z., 2009. Pigeons (Columba livia) are a suitable experimental model for Neospora caninum infection in birds. Vet. Parasitol. 159, 149-153.

Moraes-Filho, J., Krawczak, F.S., Costa, F.B., Soares, J.F., Labruna, M.B., 2015 Comparative evaluation of the vector competence of four south american populations of the Rhipicephalus sanguineus group for the bacterium Ehrlichia canis, the agent of canine monocytic ehrlichiosis. PLoS One 10, e0139386.

Murphy, G.L., Ewing, S.A., Whitworth, L.C., Fox, J.C., Kocan, A.A., 1998. A molecular and serologic survey of Ehrlichia canis, E. chaffeensis, and E. ewingii in dogs and ticks from Oklahoma. Vet. Parasitol. 79, 325-339.

Nijhof, A.M., Balk, J.A., Postigo, M., Jongejan, F., 2009. Selection of reference genes for quantitative RT-PCR studies in Rhipicephalus (Boophilus) microplus and Rhipicephalus appendiculatus ticks and determination of the expression profile of Bm86. BMC Mol. Biol. 10, 112.

Nordgren, R.M., Craig, T.M., 1984. Experimental transmission of the Texas strain of Hepatozoon canis. Vet. Parasitol. 16, 207-214.

Parker, R.R., Philip, C.B., Jellison, W.L., 1933. Rocky Mountain spotted fever: potentialities of tick transmission in relation to geographical occurence in the United States. Am. J. Trop. Med. Hyg. 13, 341-379.

Peleg, O., Baneth, G., Eyal, O., Inbar, J., Harrus, S., 2010. Multiplex real-time qPCR for the detection of Ehrlichia canis and Babesia canis vogeli. Vet. Parasitol. 173, 292-299.

Regendanz, P., Muniz, J., 1936. O Rhipicephalus sanguineus como transmissor da piroplasmose canina no Brasil. Mem. Inst. Oswaldo Cruz 31, 81-84.

Rodriguez-Vivas, R.I., Trees, A.J., Rosado-Aguilar, J.A., Villegas-Perez, S.L., Hodgkinson, J.E., 2011. Evolution of acaricide resistance: phenotypic and genotypic changes in field populations of Rhipicephalus (Boophilus) microplus in response to pyrethroid selection pressure. Int. J. Parasitol. 41, 895-903.

Rosario-Cruz, R., Almazan, C., Miller, R.J., Dominguez-Garcia, D.I., Hernandez-Ortiz, R., de la Fuente, J., 2009. Genetic basis and impact of tick acaricide resistance. Front. Biosci. 14, 2657-2665.

Sanches, G.S., de Oliveira, P.R., Andre, M.R., Machado, R.Z., Bechara, G.H., Camargo-Mathias, M.I., 2012. Copulation is necessary for the completion of a gonotrophic cycle in the tick Rhipicephalus sanguineus (Latreille, 1806) (Acari: Ixodidae). J. Insect Physiol. 58, 1020-1027.

Sanches, G.S., 2013. Comparação biológica, morfológica e molecular entre carrapatos do Complexo Rhipicephalus sanguineus (Acari: Ixodidae). PhD Thesis. Universidade Estadual Paulista.

Sen, S.K., 1933. The vector of canine piroplasmosis due to Piroplasma gibsoni. Ind. J. Vet. Sci. Anim. Husb. 3, 356-363.

Shayan, P., Hooshmand, E., Rahbari, S., Nabian, S., 2007. Determination of Rhipicephalus spp. as vectors for Babesia ovis in Iran. Parasitol. Res. 101, 1029-1033.

Sonenshine, D.E., 1991. Biology of Ticks. Oxford University Press, New York.

Vandesompele, J., De Preter, K., Pattyn, F., Poppe, B., Van Roy, N., De Paepe, A., Speleman, F., 2002. Accurate normalization of real-time quantitative RT-PCR data by geometric averaging of multiple internal control genes. Genome Biol. 3, RESEARCH0034.

Wang, J., Pantopoulos, K., 2011. Regulation of cellular iron metabolism. Biochem. J. 434, 365-381.

Weiss, B.L., Reuben Kaufman, W., 2001. The relationship between 'critical weight' and 20-hydroxyecdysone in the female ixodid tick, Amblyomma hebraeum. J. Insect Physiol. 47, 1261-1267.

Wellman, M.L., Krakowka, S., Jacobs, R.M., Kociba, G.J., 1988. A macrophage-monocyte cell line from a dog with malignant histiocytosis. In Vitro Cell. Dev. Biol.: J. Tissue Cult. Assoc. 24, 223-229.

Woldehiwet, Z., Ristic, M., 1993. Rickettsial and Chlamydial Diseases of Domestic Animals, 1 st ed. Pergamon Press, Oxford, England; New York.

Xu, G., Fang, Q.Q., Keirans, J.E., Durden, L.A., 2004. Ferritin gene coding sequences are conserved among eight hard tick species (Ixodida: Ixodidae). Ann. Entomol. Soc. Am., 567-573.

Zivkovic, Z., Torina, A., Mitra, R., Alongi, A., Scimeca, S., Kocan, K.M., Galindo, R.C., Almazan, C., Blouin, E.F., Villar, M., Nijhof, A.M., Mani, R., La Barbera, G., Caracappa, S., Jongejan, F., de la Fuente, J., 2010. Subolesin expression in response to pathogen infection in ticks. BMC. Immunol. 11, 7. 